\title{
CODE OF ETHICS URGENCY IN THE IMPLEMENTATION OF GENERAL ELECTION IN INDONESIA ${ }^{\Omega}$
}

\author{
Jeremia Alexander Wewo ${ }^{1}$, Kotan Y. Stefanus ${ }^{2}$, and Umbu Lili Pekuwali ${ }^{2}$ \\ ${ }^{1}$ Master's Degree Program, Nusa Cendana University, Kupang - Indonesia \\ E-mail: jeremiawewo92@gmail.com \\ ${ }^{2}$ Faculty of Law, Nusa Cendana University, Kupang - Indonesia
}

\begin{abstract}
The mirror of state of democracy is election. Three institutions that organize General Election include General Election Commission, Election Supervisory Agency and Election Organizer Ethics Council. This study applies normative legal method. Code of Ethics constitutes significant meaning in every General Election for governing the General Election organizer to have integrity and high dedication. Code of Ethics and law in general election are inseparable; Code of Ethics is the guidelines for the election organizer to act and behave while the law is the foundation of a General Election implementation. In order to realize a democratic and quality General election then a General election process must be based on Code of Ethics and law.
\end{abstract}

Keywords: general election, election organizer, code of ethics, law

\begin{abstract}
Abstrak
Cermin dari negara demokrasi adalah Pemilihan Umum. Terdapat tiga lembaga yang menyelenggarakan Pemilihan Umum, Komisi Pemilihan Umum, Badan Pengawas Pemilihan Umum, dan Dewan Kehormatan Penyelenggara Pemilihan Umum. Lembaga penyelenggara Pemilihan Umum diatur oleh kode etik penyelenggara Pemilihan Umum. Penelitian ini menggunakan metode penelitian hukum normatif. Kode etik memiliki arti yang penting dalam setiap Pemilihan Umum, karena kode etik dapat mengatur dan membentuk penyelenggara Pemilihan Umum untuk memiliki integritas dan dedikasi tinggi. Kode etik dan hukum dalam penyelenggaraan Pemilihan Umum tidak dapat dipisahkan, kode etik merupakan dasar pedoman penyelenggara Pemilihan Umum dalam bertindak dan berperilaku, serta hukum adalah dasar pelaksanaan suatu Pemilihan Umum. Untuk mewujudkan Pemilihan Umum yang demokratis dan berkualitas maka suatu proses Pemilihan Umum harus berdasarkan kode etik dan aturan hukum Pemilihan Umum.
\end{abstract}

Kata kunci: pemilihan umum, penyelenggara pemilihan umum, kode etik, hukum

\section{Introduction}

Indonesia adheres democracy and nomocracy. This juridical foundation is stated in Article Number 1 paragraph 2 of the 1945 Constitution which stated "sovereignty is in the hands of the people and implemented according to the Constitution". ${ }^{1}$ Based on the constitution, Indonesia believes in people's sovereignty which is exceptional and democracy as its base. Democracy is often identified with the jargon of "go-

$\Omega$ This article is part of thesis on Law Master's Degree Program Universitas Nusa Cendana Kupang

Bambang Satriya, "Urgensi Integritas Penyelenggara Pemilihan Umum dalam Menegakkan Kedaulatan Rakyat", Jurnal Etika dan Pemilu, Vol. 3 No. 1, March 2017, p. 10. vernment of the people, by the people, and for the people, demonstrating that the legitimacy of democracy is people's sovereignty. The nomocratic understanding can be proven by referring to the provisions of Article 1 paragraph 3 of the 1945 Constitution which affirms that "Indonesia is a state of law". This constitutional line is used as the basic understanding to the rule of law which principally believes in principle of law supremacy. It means that all life aspects of the nation must refer to the applicable law. ${ }^{2}$

The fundamental principle of democracy applied in many countries is the General Elec-

2 Ibid. 
tion. Even general election is a democratic instrument in most countries. Polling by general election mechanism functions as a means of implementing people's sovereignty. ${ }^{3}$ General election is a mandate of the constitution that must be implemented by the government to ensure and protect the implementation of people's sovereignty in accommodating their political rights. ${ }^{4}$ It becomes a moment carried out by Indonesian government every five years. It is the embodiment of democracy system which has been mandated by Pancasila and 1945 Constitution. ${ }^{5}$ In Indonesia, it has been known that there are three types of General Election, namely Presidential Election, Legislative Election and Regional Head Election. Beside the people contribution, the organizers are required to organize and supervise the election. In the implementation, the general election organizers play a strategic role even it can be called as the key for the implementation series which is honest, fair and morally accountable political activities, ethics, law and politics. ${ }^{6}$ The institutional design of the organizing of the General Election includes three (3), namely the General Elections Commission (KPU), Election Supervisory Agency (Bawaslu), and Election Organizer Ethics Council (DKPP) which constitute a unity of functions in realizing fairness and honesty in the election. The institutions of the General Elections Commission and the General Election Supervisory Agency directly related to the implementation of the electoral management body, while the General Election Organizer Ethics Council is not. $^{7}$

Ibid.

Aryo Fadlian, "Pengaruh Putusan Dewan Kehormatan Penyelenggara Pemilihan Umum terhadap Hasil Pemilihan Gubernur Lampung 2014", Jurnal Fiat Justisia, Vol. 10 No. 4 October-December 2016, p. 772.

5 Sunny Ummul Firdaus, "Pengawas Pemilihan Umum sebagai Guardian of The Election (Penjaga Pemilu) Pasca Ditetapkannya Pemilu Serentak", Jurnal Etika dan Pemilu, Vol. 3 No. 3, September 2017, p. 76.

6 Suyanto Londrang, "Eksistensi Dewan Kehormatan Penyelenggara Pemilihan Umum dalam Upaya Mendukung Tata Kelola Pemerintahan yang Baik Melalui Penegakan Kode Etik Penyelenggara Pemilihan Umum", Jurnal Etika dan Pemilu, Vol. 3 No. 3, September 2017, p. 38.

7 Muh. Salman Darwis, "Menakar Independensi Penyelenggara Pemilihan Umum dalam Pemilihan Kepala Daerah Serentak 2015", Jurnal Etika dan Pemilu, Vol. 1 No. 2, August 2015, p. 23.
In its duties and responsibilities, the general election organizers are governed by the Code of Ethics. ${ }^{8}$ Code of Ethics of the general election means the unity of the foundation, moral, ethical and philosophical norms which serve as guidelines for the conduct of the required, prohibited, appropriate or inappropriate election organizers, conducted in all acts and behavior (Article 1 paragraph 6 of Joint Regulatory of General Election Commission, Election Supervisory Agency, Election Organizer Ethics Council Number 13, 1 and Number 1 Year 2012 of the Code Ethics on the General Election Organizer).

The interest of Code of Ethics arranged by Election Organizer Ethics Council is binding and must be obeyed by every member of General Election Commissions along with their members as well as Election Supervisory Agency along with their members. The Code of Ethics is given through Joint Regulatory of Election Commission Council, Election Supervisory Agency, and Election Organizer Ethics Council Number 13, Number 11, and Number 1 Year 2012 of The Code of ethics of Election Organizer. ${ }^{9}$ Nonetheless, the interest of Code of Ethics is not immediately obeyed by the election organizers. ${ }^{10} \mathrm{Ba}$ sed on the Election Organizer Ethics Council's data, in the event of Regional Head Election 2017, the election organizers that violate Code of Ethics were still found.The details are that the numbers of complaint which goes into Election Organizer Ethics Council is approximately 311 complaints. Out of 311 complaints, 141 electoral members are proven to violation against code of ethics after going through the process of court led by Election Organizer Ethics Council.

Observing the intensity of the violation against Code of Ethics that occur, the writer assumes that the position of code of ethics as a

8 See introduction by editor entitled "Etika Peserta Pemilu”, Jurnal Etika dan Pemilu, Vol. 2 No. 3, October 2016, p. 5.

9 Muh. Risnain, "Menimbang Gagasan Kode Etik Peserta Pemilihan Umum", Jurnal Etika dan Pemilu, Vol. 3 No. 1 June 2017, p.25.

10 Rahman Yasin and Muhammad Saihu, 2017, Memori Jabatan DKPP 2012-2017, Jakarta: Dewan Kehormatan Penyelenggara Pemilihan Umum, p.157. 
manual, guidelines, and reference in carrying out its duties and responsibilities seems not well interpreted. Moreover, the legal standing as the code of ethics protector itself does not give any impacts on the implementation of the democracy process in our country.

The impacts of the violation against code of ethics committed by the election organizer puts a disgrace in the process of the election which is Luber Jurdil (Direct, Free, Confidential, Honest, and Fair). This country has unwittingly experienced an extraordinary moral and ethics degradation in legal action of the election. In penal code, corruption is known as an extraordinary crime. Therefore, the code violation in the process of general election is known as an extraordinary ethical crime.

It certainly becomes a great task for the government, every member of the election organizer, Election Organizer Ethics Council, and society in order to welcome democracy party of Regional Head Election along with Legislative Election, and Presidential Election 2019. Based on this background this paper will discuss about: first, the important meaning of code of ethics in General Election; and second, the connection between code of ethics and law to prevent code violation in the General Election.

\section{Research Methods}

This is a normative or doctrinal law research on secondary data in form of primary law object, secondary law object, and tertiary law object. Moreover, the research applies Statute approach, ${ }^{11}$ cases approach, ${ }^{12}$ and conceptual approach $^{13}$ with prescriptive specification. The analysis is conducted through interpretation by paying attention on its consistency among theory of law, principle of law, and rule of law which are relevant to the formulated problems.

\section{Discussion}

The Code of Ethics Urgency in the Implementation of General Election in Indonesia

\footnotetext{
11 Peter Mahmud Marzuki, 2005, Penelitian Hukum, Jakarta: Kencana Prenadia Group, p. 136.

12 Ibid, p. 158.

13 Ibid, p. 177.
}

The term "democracy" originates from two words which is demos that means people, and kratos or cratein which means government that it can be interpreted as government of people, or government of the people, by the people, and for the people. Democracy is a form or mechanism of the government system of a country as an effort of bringing people's sovereignty into reality over the state to be run by the government. ${ }^{14}$ According to Jean Jaques Rousseau, democracy is a step or process that has to be passed by a country to achieve prosperity. Rousseau's statement is as if to say that democracy for a country is a learning toward the development of the perfect state administration. ${ }^{15}$

The consistency of democracy in Indonesia certainly cannot be separated from the existence of the election. A successful election is an election that prioritizes the principles of democracy. By the existence of elections, the principles of democracy can be materialized including the occurrence of the movement of state power from the previous holder to the newer one peacefully. Election is a one of the principles to uphold democracy system.

The purpose of the general election are: first, to implement the democratic principles by selecting the representatives in legislative stage including the regional head and vice, also president and the vice. All are carried out to make the people participate in constitutional life. In this regard, general election is done to choose people's representatives and district's representatives as well as forming democratic and strong governance with society's support to reach the national goal. Second, the similarities on law is realized by the existence of the election. In an election contest, equal treatment by each member of election organizers to every candidate, whether it is the election participants or other parties involved in the election is required to avoid discrimination. Third, free

\footnotetext{
14 Jailani, "Sistem Demokrasi di Indonesia di tinjau dari Sudut Hukum Ketatanegaraan", Jurnal Inovatif, Vol. 8 No. 1, January 2015, p. 136.

15 Thalhah, "Teori Demokrasi dalam Wacana Ketatangeraan Perspektif Pemikiran Hans Kelsen", Jurnal Hukum Ius Quia lustum, Vol. 16 No. 3, July 2009, p. 414-415.
} 
election means citizen is free to determine their representatives to be the legislative, regional head and the vice, president and the vice, without force from any parties. The fourth, freedom to participate and position as a political party is given. In this case, political party is given authority by the Law to determine the representatives through multi parties system which then would be chosen by citizen through the election. Fifth, it is the developed appreciative behavior towards minority or individuals by more prioritizing on how to use persuasive ways and discussion instead of being coercive and repressive. In the perspective of general election, there is no majority and minority. All have the same position and given the same chance.

Code of ethics is vital in process of election to realize the democratic principles. It stands for several reasons of the significance of Code of Ethics in the election. The result of the democratic election is indeed the happiness of Indonesian people. Indonesian people undoubtedly expect for the successful election process without any violation.

Violation on ethics done by member of election organizer can affect the result of an election. In regard to this, Indonesian citizen believe that a District Head or leader who is unfairly elected would tend to violate the existing rules in his administration. It is the first reason initiated by the writer about the important meaning of code of ethics. In this case, the position of the code must be able to neutralize any code of ethics violation happening in every constellation of the election process and creating the process of real democracy.

The second reason refers to the condition of the Joint Regulatory of Election Commission Council, Election Supervisory Agency, and Election Organizer Ethics Council Number 13, 11, and 1 Year 2012 on Code of Ethics of Election Organizers on Article 2 paragraph 1 stated "Code of Ethics Based on Pancasila". It means that every point written in the article about Ethical Code of Election Organizers uses Pancasila as its basis. In that case, if Code of Ethics is interpreted well and obeyed by the election organizers, it will be the same as if we implement the existing value of Pancasila.

Third reason, for example, is in the process of the Regional Head that there is a relative from the member of election organizer enrolls as a candidate in that district. Thus there is a high chance for the member to cheat and project his relative. At this point is where ethical code of the election needs to show its existence. Code of ethics must be there as a light in overcoming dilemmatic moral experienced by the member of election organizer.

The fourth reason, in the terms of Joint Regulatory of Election Commission Council, Election Supervisory Agency, and Election Organizer Ethics Council Number 13, 11, and 1 Year 2012 on Code of Ethics of Election Organizers, contains things that must not be done by every member of election organizers. It shows the position of ethical code as a basis, reference, and guidelines for every member of election organizers. If those things are obeyed, violation of code of ethics could be neutralized.

Writer argues that ethical code of election organizer would make work ethic on every single member of election organizer to be virtuous organizer of election who do their job as the scientific responsibility and individual moral integrity on the devotion to others by respecting and upholding the truth and fairness upon money and position. Other than creating work ethic, code of ethics also give moral guidance for the election organizers so they would be able to do their duty and responsibility as well to prevent them from deviant behavior including code of ethics violation.

\section{The Relation of Code of Ethics and Law to Pre- vent Ethics Violation}

To discuss code of ethics and law, we should know their history first. Election organizer code of ethics have existed since the application of Law Number 22 year 2007 that is also written in election commission rule Number 31 Year 2008 on Code of Ethics of Election. At that time, the institution which handled code of ethics violation was Election Commission Ethics Council. Furthermore, in 2012 Election Organ- 
izer Ethics Council (DKPPU) replaces the Election Commission Ethics Council duty.

Actually law have existed since the first general election in 1955 since the basis to conduct general election is one of the law products. It is Law Number 18 Year 1953 on Members Election of Constituent and Representative Council and Government Regulation No. 9 Year 1954 of elections. In this context, law is the foundation and reference of general election. An election becomes valid and approved because there is a law as fixed foundation and cannot be disturbed. In ethical code matter, it has been examined that in general election code of ethics is a basic or guidance for election organizer to conduct the election. Organizer's duty is to con-duct general election; thus, the election would be in mess if they do not have rules.

The relation between code of ethics and law is crucial because both of them are really important in conducting election. The researcher believes there is no general election without law and Code of Ethics. Consequently, as if code of ethics and election are inseparable two sides of the same coin. Moreover, researcher thought that election would success if code of ethics and law are also well interpreted.

To prevent code of ethics violation is DKPPU duty. The preventing activities are: first, Coordination of three institutions ${ }^{16}$ (General Election Commission, Election Supervisory Agency, and Election Organizer Ethics Council). It aims to discuss the problems in previous election to develop a better election in the future. Second, Socialization of code of ethics of election organizer. The purpose of this activity is to give knowledge about code of ethics in general election and any potential problems in election processes to regional head, election organizer, politics parties, mass media, mass organization, civitas academica, and community in general. ${ }^{17}$

Third, focus group discussion (FGD). This activity aims to explore all power, weaknesses, opportunity, and general or particular threat of general election organizer in the local area. The

16 Rahman Yasin and Muhammad Saihu, Op.Cit, p.200.

17 Ibid, p.206. general problems are all of problems that often appear in various places meanwhile special problems are obstacles that only appear in particular area. The problems are identified and then categorized based on particular reason to be settled with alternative solutions. ${ }^{18}$ The purpose of FGD is adequate information to prevent code of ethics violation by organizer in regional. The FGD participants are specially from organizer of general election (General Election Commission and Election Supervisory Agency) from province and district/city level. ${ }^{19}$

Fourth, Technical guidance. The purpose of this activity is to give technical knowledge to organizers of general election to be capable to professionally serve complaints about code of ethics violations. ${ }^{20}$ Fifth, national coordination meeting of local inspection team. The formation of this team is the newest innovation by Election Organization Ethics Council (DKPPU) to face many reports of alleged code of ethics violations. ${ }^{21}$

As the newest innovation, local inspection team should learn more. Many interesting experiences are found during inspection team working. Besides, there are problems that become obstacle. The purpose of coordination meeting are to evaluate thoroughly, plan the future agenda, and share experience. ${ }^{22}$

\section{Conclusion}

Code of Ethics is important in general election since it guarantees the implementation of Pancasila and democratic values, provides strength when the organizer in their mental dilemma, as foundation of the organizer in conducting their duties. Code of ethics and law cannot be separated because Code of ethics is foundation of general election organizer to behave while law is foundation the implementation of general election.

\section{Suggestion}

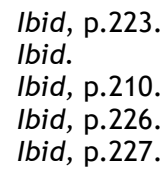


In order to create general election that democratic and has a good quality, therefore, an election process must be based on code of ethics and law of general election.

\section{References}

Darwis, Muh. Salman. "Menakar Independensi Penyelenggara Pemilihan Umum dalam Pemilihan Kepala Daerah Serentak 2015". Jurnal Etika dan Pemilihan Umum. Vol. 1 No. 2. August 2015. Pp. 22-35;

Editor Jurnal Etika dan Pemilu. "Etika Peserta Pemilu". Jurnal Etika dan Pemilu. Vol. 2 No. 3. October 2016. Pp. 2-7;

Fadlian, Aryo. "Pengaruh Putusan Dewan Kehormatan Penyelenggara Pemilihan Umum terhadap Hasil Pemilihan Gubernur Lampung 2014". Jurnal Fiat Justisia. Vol. 10 No. 4. October-December 2016. Pp. 771788. DOI: 10.25041/fiatjustisia.v10no4;

Firdaus, Sunny. Ummul. "Pengawas Pemilihan Umum sebagai Guardian of The Election (Penjaga Pemilu) Pasca Ditetapkannya Pemilu Serentak". Jurnal Etika dan Pemilu. Vol. 3 No. 3. September 2017. Pp. 75-83;

Jailani. "Sistem Demokrasi di Indonesia ditinjau dari Sudut Hukum Ketatanegaraan". Jur- nal Inovatif. Vol. 8 No. 1. January 2015. Pp.134-147;

Londrang, Suryanto. “Eksistensi Dewan Kehormatan Penyelenggara Pemilihan Umum dalam Upaya Mendukung Tata Kelola Pemerintahan yang Baik Melalui Penegakan Kode Etik Penyelenggara Pemilihan Umum". Jurnal Etika dan Pemilu. Vol. 3 No. 3. September 2017. Pp. 37-51;

Marzuki, Peter. Mahmud. 2005. "Penelitian Hukum”. Jakarta:Kencana Prenadia Group;

Muhammad, Saihu and Yasin Rahman. 2017. Memori Jabatan DKPP 2012-2017. Jakarta: Dewan Kehormatan Penyelenggara Pemilihan Umum;

Risnain, Muh. "Menimbang Gagasan Kode Etik Peserta Pemilihan Umum". Jurnal Etika dan Pemilu. Vol. 3 No. 1. June 2017. Pp.21-30;

Satriya, Bambang. "Urgensi Integritas Penyelenggara Pemilihan Umum dalam Menegakkan Kedaulatan Rakyat”. Jurnal Etika dan Pemilu, Vol. 3 No. 1. March 2017. Pp. 9-20;

Thalhah. "Teori Demokrasi dalam Wacana Ketatangeraan Perspektif Pemikiran Hans Kelsen”. Jurnal Hukum lus Quia lustum, Vol. 16 No. 3. July 2009. Pp. 413-422. DOI: 10.20885/iustum.vol16.iss3.art6. 